\title{
The Organizational Culture and Competence of School Principals in Coping With the Spread of Covid-19 in Schools
}

\author{
Suherman* and Suparno \\ Department of Non-Formal Education, Faculty of Teacher Training and Education, Sultan Ageng \\ Tirtayasa University \\ *Corresponding author. Email: suherman@untirta.ac.id
}

\begin{abstract}
Organizational culture and competence are two phenomena that the Principal needs to understand in coping with Covid-19 in the school environment. This research aimed to determine the relationship between organizational culture and the competence of school principals in overcoming the Covid-19 in schools. The research was carried out on the Principal of Junior High School in Pandeglang, Banten. The researchers used the descriptive-associative method with a total sample of 53 people. The results showed a relationship between organizational culture and competence in overcoming Covid-19 in the school environment. However, partially there are differences between understanding organizational culture and competence in dealing with Covid-19. The analysis results between understanding organizational culture on Covid-19 countermeasures with the competence of the Principal as a control variable showed a result of 0.037 . Meanwhile, the results of the analysis between the competences of the Principal in facing Covid-19 with organizational culture as a control variable obtained results of 0.766. The analysis results between the competences of the Principal in tackling Covid-19 with organizational culture as a control variable obtained 0.766. It is assumed that compared to organizational culture will have implications for school development and other matters, including the handling of Covid-19 in the school environment.
\end{abstract}

Keywords: Organizational culture, Competence of school principals, Descriptiveassociative.

\section{INTRODUCTION}

Organizational culture has characteristics that are useful for assessing agencies and as a basis for shared understanding within the agency concerned, how employees behave, and creating cultural cohesiveness that varies from one another. According to Ernawan [1], organizational culture is a way of life and lifestyle of an organization, reflecting the values or beliefs held by members of the organization. Then, Luthans [2], culture of organizational is a fundamental supposition design made or created by specific gatherings when adjusted to external problems and internal integration, which have worked quite well and are considered valuable and taught to new members to become aware of thinking and feeling a connection to the problem. Furthermore, Sutrisno [3] stated that organizational culture is an arrangement of qualities, convictions, or standards that have for quite some time been substantial, are settled upon and followed by individuals from an association as a set of accepted rules and critical thinking.

On the other hands, organizational culture is the arrangement of hidden convictions, qualities, standards, and methods of communicating inside an association. It characterizes and establishes an extraordinary climate to work in.Things like an association's assumptions, vision, theory, picture, connections inside the workplace, and outside of the workplace additionally characterize what is the issue here.Organizational culture characterizes what each worker's conduct ought to be and how they ought to connect with the remainder of the association. It characterizes how you feel about functioning 
for the association [4]. Regarding problemsolving, currently, there is the spread of the coronavirus disease known as Covid-19.

The spread of Covid-19 does not rule out the possibility of occurring in a school environment.The spread of covid-19 is generally transmitted through contact with droplets from the respiratory tract, not through the air.Individuals can get Covid-19 from others who have the infection. Coronavirus can spread from individual to individual through beads from the nose or mouth that come out when an individual with Covid-19 hacks or breathes out. This sparkle at that point falls on close-by objects. The person who touches the object then touches the eyes, nose, and mouthcan contract the Covid-19. Besides, a transmission can also occur when people breathe in the droplets from a cough or breathe from a person who has been infected by Covid-19. Therefore, it is important to maintain a physical distancing of more than 1 meter for the sick person. Also, the Principal needs to move his organization and have competence so that Covid-19 does not spread in the school environment.

One of the alternatives is an online classroom that prepares the distance of the understudies with the ability to act the adapting needs, esteem the results of learning movement, and quicken students to the expert credentialing by using an effective conveyance of the web-basedsystem [5][6]. This situation needs leadership and might be much more significant for understudies in constantly low-performing schools [7]. The principal inspired the teacher to create the learning activities that the understudies believed that this learning activity was fun and gave them much information so they canstudy and fun [8].

Competence is theskills and abilities controlled by a person so that he can perform cognitive, affective, and psychomotor activities as well as possible. Sagala [9] stated that competence is "a set of knowledge, skills, and behavior that must be possessed by the principal in carrying out duties and responsibilities." Then, Mc. Ahsan, cited in Mulyasa [10], the competency "is knowledge, skill, and abilities or capabilities that a person archives, which become part of his or her being to the extent he or she can perform a particular cognitive performance.

The examination has reliably demonstrated that principals assume a basic part in deciding the nature of instructing, and thus, understudy learning and accomplishment [11]. Some meta-logical surveys propose that viable administrators are exceptionally capable in these following things: 1) setting up and passing on the school's vision, objectives and assumptions by demonstrating optimistic practices and advancing information use for continuous improvement; 2) fabricating instructors' expert limit by giving focused on and work inserted proficient turn of events, ensuring instructional time, and choosing teachers who are the "right fit" for the school; 3) making a steady association for learning by sharing and appropriating initiative, comprehension and expanding on variety, and deliberately gaining and distributing assets; 4) encouraging a great understudy learning experience by creating and checking educational program, guidance, and evaluation, and establishing learning conditions that are customized, safe, and methodical; and 5) interfacing with outside accomplices who can uphold satisfaction of school objectives, and building beneficial and collective associations with families. While these important abilities are pertinent for a scope of school settings, pioneers working in shifting school conditions (e.g., high or low poverty, urban or rural) should ultimately decide how best to sanction them to improve educating and learning processes [12].

Based on this, the competence of the principal is a synergy of knowledge, attitudes, and skills, as well as aspects of values and morals, which are owned by a person who is given the duties and responsibilities as head of an education unit, to serve himself as a servant of the state and a public servant. These domains need to be implemented in an effort to prevent the spread of Covid-19 in the school environment. For example, the principal created such activities in another finding was that the availability of reading books in addition to textbooks for their reading sources was useful in assessing their reading skill. It was proved that learning skills show children's literacy skills as an alternative for learning in the Pandemic Covid-19 
situation [13]. Besides, speaking is one of the beneficial aptitudes where this viewpoint turns into a parameter of successful instructing and learning in the room of a study [14]. This alternative must be consulted with the parents. Guardians can assume a significant job in aiding their kids adapt to the present circumstance. Schools should work with guardians to shape a methodology to help understudies battle depression in the present circumstance. Understudies are powerless against affect their emotional well-being on the off chance that they are not really focused on appropriately. The two guardians and educators need legitimate advising to have the option to help the kids in the pandemic situation [15] such as the use of quizzes in teaching online sessions [16].

\section{METHODS}

The study was conducted to know the influence of organizational culture and school principals' competence in overcoming covid19. The research was carried out on the Head of Junior High School in Pandeglang. The distance between districts in the regency is relatively far, with different internet facilities. Referring to the number of schools, the
To face the challenges of the 4.0 industrial revolution era, it is necessary to improve the nature of the competence of human resources (HR) in the fields of manpower, health, security, economy, food, and education. This is because there will be a change in the character of the business that requires workers to have new skills. Due to the changing character of the industry, new jobs will emerge, which will require new skills. Our government must prepare human resources to have hard skills and soft skills in this new job [17]. Especially in linguistics awareness, it is a meaning of communication by who people gives and receives information from one society to another society.

number of respondents in this study were 53 junior high school principals. This type of research used the descriptive associative method. In the recentresearch, a theory is built that can serve to explain, predict, and control a symptom. Therefore, this research was conducted with the following design.

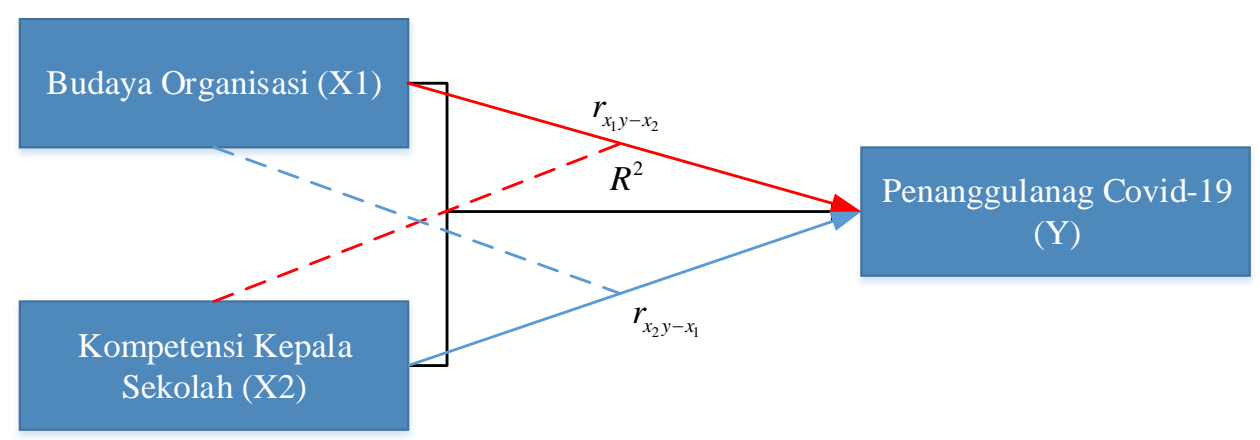

Figure 1 Research design.

Referring to figure 1 above, organizational culture is an independent variable, and the response to Covid-19 is the dependent variable, while the Principal's competence is a control variable. Then, in the second scenario, the competence of the Principal is the independent variable, and the response to Covid-19 is the dependent variable, while the organizational culture is the control variable.
Furthermore, in the third scenario, the Principal's organizational culture and competence are independent variables, while the response to Covid-19 is the dependent variable. Based on some research variables and constellations above, the analysis of the relationship between variables $\mathrm{X} 1$ and $\mathrm{Y}$ and between variables $\mathrm{X} 2$ and $\mathrm{Y}$ uses partial correlation, with the following equation. 


$$
r_{x_{1} y-x_{2}}=\frac{r_{x_{1} y}-\left(r_{x_{2} y}\right)\left(r_{x_{1} x_{2}}\right)}{\sqrt{\left[1-\left(r_{x_{2} y}\right)^{2}\right]\left[1-\left(r_{x_{1} x_{2}}\right)^{2}\right]}}
$$

and

Where: rxly is the correlation coefficient between $\mathrm{X} 1$ and $\mathrm{Y}, \mathrm{rx} 2 \mathrm{y}$ is the correlation coefficient between $\mathrm{X} 2$ and $\mathrm{Y}$, and $\mathrm{rx} 1 \mathrm{x} 2$ is

$$
r_{x_{2} y-x_{1}}=\frac{r_{x_{2} y}-\left(r_{x_{1} y}\right)\left(r_{x_{1} x_{2}}\right)}{\sqrt{\left[1-\left(r_{x_{1} y}\right)^{2}\right]\left[1-\left(r_{x_{1} x_{2}}\right)^{2}\right]}}
$$

the correlation coefficient between $\mathrm{X} 1$ and $X 2$. The aspects and indicators of each of these variables are shown in Table 1 below.

\begin{tabular}{|c|c|c|c|}
\hline Variable & Variable Concept & & Indicator \\
\hline $\begin{array}{l}\text { Organizational Culture } \\
\text { (X1) }\end{array}$ & $\begin{array}{ll}\text { 1) } & \text { Values system set } \\
\text { 2) } & \text { (values), beliefs, assumptions } \\
3) & \text { (assumptions), which have long } \\
\text { been followed by members of an } \\
\text { organization as } \\
\text { 4) } \\
5) & \text { code of conduct and } \\
6) & \text { organization } \\
\end{array}$ & $\begin{array}{l}\text { 1) } \\
\text { 2) } \\
\text { 3) } \\
\text { 4) }\end{array}$ & $\begin{array}{l}\text { individual initiative } \\
\text { Tolerance for risky actions } \\
\text { Management support } \\
\text { 4) Control }\end{array}$ \\
\hline $\begin{array}{l}\text { Principal Competence } \\
\text { (X2) }\end{array}$ & $\begin{array}{l}\text { 1) Abilities that must be mastered by } \\
\text { the Principal, in the form of knowledge, } \\
\text { attitudes, skills, in leading an educational } \\
\text { unit }\end{array}$ & $\begin{array}{l}\text { 1) } \\
\text { 2) } \\
\text { 3) } \\
\text { 4) } \\
\text { 5) }\end{array}$ & $\begin{array}{l}\text { Personality } \\
\text { Supervision } \\
\text { Managerial } \\
\text { Entrepreneurship } \\
\text { 5) Social }\end{array}$ \\
\hline $\begin{array}{l}\text { Countermeasures for } \\
\text { Covid-19 (X) }\end{array}$ & $\begin{array}{l}\text { 1) Work with WFH and WFO while } \\
\text { learning online and offline }\end{array}$ & $\begin{array}{l}\text { 1) } \\
\text { 2) } \\
\text { 3) } \\
\text { learning } \\
\text { 4) }\end{array}$ & $\begin{array}{l}\text { Effectiveness of WFH } \\
\text { Effectiveness of WFO } \\
\text { The effectiveness of online } \\
\text { Offline learning schemes }\end{array}$ \\
\hline
\end{tabular}

Table 1. Aspects and variable indicators

\section{RESULT AND DISCUSSIONS}

1. Organizational Culture and Covid-19 Handling with the Competence of the Principal as the control variable
The results of descriptive analysis, the organizational culture for the prevention of Covid-19 are shown in Table 2 below.

Table 2. Results of descriptive analysis of Covid-19 countermeasures at SMP NegeriPandeglang Regency

Descriptive Statistics

\begin{tabular}{llll} 
& Mean & Std. Deviation & N \\
\hline Cultural Organization & 46.0377 & 2.61624 & 53 \\
\hline Overcoming Covid-19 Pandemic & 139.6415 & 6.76272 & 53 \\
\hline Principals' Competence & 38.3019 & 2.24109 & 53 \\
\hline
\end{tabular}

Based on Table 2 above, school principals' average organizational culture and competence for 53 State Junior High School (SMP) Principals in Pandeglang Regency show that understanding organizational culture is higher than the average school's average competency principals. The average difference between organizational culture and the competence of school principals in Pandeglang is $16.80 \%$. Furthermore, the analysis of the handling of Covid-19 with the competence of the Principal as the control variable isshown in Table 3 below. 
Table 3. The results of the analysis of Covid-19 countermeasures with the competence of the Principal as the control variable

\begin{tabular}{|c|c|c|c|c|}
\hline \multicolumn{5}{|c|}{ Correlations } \\
\hline Control Variables & & & $\begin{array}{c}\text { Cultural } \\
\text { Organization }\end{array}$ & $\begin{array}{l}\text { Coping with } \\
\text { Covid }\end{array}$ \\
\hline \multirow[t]{6}{*}{ The Principal's' Competence } & Cultural Organization & Correlation & 1.000 & .037 \\
\hline & & Significance (2-tailed) & & .792 \\
\hline & & $\mathrm{df}$ & 0 & 50 \\
\hline & Coping with Covid & Correlation & .037 & 1.000 \\
\hline & & Significance (2-tailed) & .792 & . \\
\hline & & $\mathrm{df}$ & 50 & 0 \\
\hline
\end{tabular}

Based on Table 3 above, the relationship between organizational culture and Covid-19 countermeasures with the Principal's competency control variable is 0.037 , and the value is still positive. This means that considering the understanding of the

2. Principal's Competence and Covid-19 Prevention with Organizational Culture as a control variable
Principal's competence, there is still a positive correlation between organizational culture and the response to Covid-19. This is under the research results by Murfi, Fathurrochman, Atika, \& Jannana [19], which concluded that successful schools consistently show strong aspects of effective school leadership.

The analysis results of the handling of Covid-19 with organizational culture as the control variable are shown in thetable below.

Table 4. The results of the analysis of Covid-19 control at SMP Negeri Pandeglang with organizational culture as the control variable

Control Variables Correlations

\begin{tabular}{lllr|r} 
Control Variables & & $\begin{array}{c}\text { The Principal's' } \\
\text { Competence }\end{array}$ & \multicolumn{2}{c}{$\begin{array}{c}\text { Overcoming } \\
\text { Covid }\end{array}$} \\
\hline $\begin{array}{lllr}\text { Cultural } \\
\text { Organization }\end{array}$ & Principal Competence & Correlation & 1.000 & .766 \\
\cline { 2 - 5 } & Significance (2-tailed) &. & .000 \\
\cline { 2 - 5 } & Overcoming Covid & Correlation & .766 & 50 \\
\cline { 2 - 5 } & Significance (2-tailed) & .000 & 1.000 \\
\hline & df & 50 &. \\
\hline
\end{tabular}

Based on Table 4 above, the relationship between the competence of the Principal and the response to Covid-19 with the variable control of organizational culture obtained a value of 0.766 , and the value is still positive. This means taking into account the high understanding of organizational culture. There is a positive relationship between the competence of school principals and the response to Covid-19. This is under the research results of Dirani [18], with the conclusion that a principal should react to these progressions by changing their capabilities by rapidly figuring out the circumstance and reacting to it by depending on their nature and HRD experts. During this pandemic, associations will prosper under a pioneer who a) gives solid jobs and reason; b) shares administration; c) imparts; d) guarantees worker's admittance to innovation; e) organizes representative's passionate solidness; f) keeps up hierarchical monetary wellbeing, and g) advances authoritative versatility.

3. Organizational Culture and Competence of School Principals against Covid-19.

The analysis of the handling of Covid-19 with organizational culture and the Principal's competence as independent variables are shown in Table 5 below. 
Table 5. The results of the analysis of Covid-19 countermeasures at SMP NegeriPandeglang with the organizational culture and competence of school principals as independent variables

\begin{tabular}{|c|c|c|c|c|}
\hline & & $\begin{array}{l}\text { Correlations } \\
\text { Coping with } \\
\text { Covid } \\
\end{array}$ & $\begin{array}{c}\text { Cultural } \\
\text { Organization }\end{array}$ & $\begin{array}{c}\text { Principal's' } \\
\text { Competence }\end{array}$ \\
\hline Pearson & Handling Covid & 1.000 & .781 & .916 \\
\hline \multirow{2}{*}{$\begin{array}{l}\text { Correlatio } \\
\mathrm{n}\end{array}$} & Cultural Organization & .781 & 1.000 & .844 \\
\hline & Principal's' Competence & .916 & .844 & 1.000 \\
\hline \multirow{3}{*}{$\begin{array}{l}\text { Sig. (1- } \\
\text { tailed) }\end{array}$} & Handling Covid & 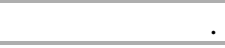 & .000 & .000 \\
\hline & Cultural Organization & .000 & & .000 \\
\hline & Principal's' Competence & .000 & .000 & \\
\hline \multirow[t]{3}{*}{$\mathrm{N}$} & Handling Covid & 53 & 53 & 53 \\
\hline & Cultural Organization & 53 & 53 & 53 \\
\hline & Principal's' Competence & 53 & 53 & 53 \\
\hline
\end{tabular}

Based on the analysis results onthe correlation between organizational culture and school principals' competence in overcoming Covid-19, the following results were obtained: the relationship between organizational culture (X1) and Covid-19 countermeasures (Y) obtained a coefficient of 0.781 . Meanwhile, based on the correlation coefficient table for the number of samples 53 was0.271. Referring to these results, we get $r$ count> r-table. Thus, it can be presumed that there is a connection between organizational culture and the response to Covid-19 in SMPofPandeglang Regency. Then, the relationship between the Principal's competence (X2) and the prevention of Covid19 (Y) obtained a coefficient of 0.916 . Referring to these results, we get r-count> rtable. Therefore, it can be concluded that there is a relationship between the competence of the Principal and the response to Covid-19 in the SMP Pandeglang Regency. Furthermore, to determine the relationship between organizational culture (X1) and the competence of school principals (X2) with the response to Covid-19 (Y) is shown in the following

Table.

Table 6. The results of the correlation analysis between organizational culture and the competence of school principals with the response to Covid-19 in SMP NegeriPandeglang

\begin{tabular}{|c|c|c|c|c|}
\hline \multicolumn{5}{|c|}{ Model Summary } \\
\hline Model & $\mathrm{R}$ & R Square & Adjusted R Square & Std. Error of the Estimate \\
\hline 1 & $.916^{\mathrm{a}}$ & .839 & .832 & 2.76823 \\
\hline
\end{tabular}

a. Predictors: (Constant), Principal's' Competence, Cultural Organization

Based on Table 6 above, the analysis results between organizational culture (X1) and the competence of the Principal (X2) with Covid-19 countermeasures (Y) obtained an $\mathrm{R}$ coefficient of 0.916 . This shows a very strong

\section{CONCLUSION}

The response to Covid-19 in schools to break the chain of spreading the virus in schools needs to be done. This is necessary to maintain students' and teachers' health for the continuity of the learning processin schools.

The learning process takes place in two schemes: first, learning takes place online, and the second scheme, learning takes place in maintaining distance. The Principal carries out both schemes based on understanding the relationship. It is even assumed that there is a strong influence between organizational culture and school principals' competence in overcoming the spread of Covid-19 in the school.

organizational culture and the Principal's competence in leading the school organization. The research results on 53 principals of State Junior High Schools in Pandeglang Regency generally show a relationship between organizational culture and school principals' competence in response to Covid-19. However, there are differences in the results of Covid-19 countermeasures if a partial analysis is used. 
The analysis results between understanding organizational culture on Covid-19 countermeasures with the competence of the Principal as a control variable showed a result of 0.037 . The relationship between the competence of the Principal and the response to Covid-19 with the variable control of organizational culture obtained a value of 0.766 . The difference in the understanding of the Principal between organizational culture and competence is very significant. Referring to these results, the Principal understands organizational culture from competence. It is assumed that school principals' weak competence compared to organizational culture, will have implications for school development and other matters, including the handling of Covid-19 in the school.

\section{REFERENCES}

[1] Ernawan, E. R. (2011). Budaya Organisasi dalam Perspektif Ekonomi dan. Bandung: Alfabeta.

[2] Luthans, F. (2006). Perilaku Organisasi. (Sepuluh, Ed.) Yogyakarta: And.

[3] Sutrisno, E. (2010). Manajemen Sumber Daya Manusia. Jakarta: Kencana Prenada Media Group.

[4] Pardot, David Cumming. "Five Dysfunction of Teams." https:/grepbeat.com/2020/10/27/petemeets-david-cummings-founder-ceo-ofpardot/, $\quad 27 \quad 10 \quad 2020$, https:/grepbeat.com/2020/10/27/petemeets-david-cummings-founder-ceo-ofpardot/. Accessed Wednesday December 2020.

[5] Pahamzah, John. "Borrowing Technique." 2020, 47=55. International Journal of English Language and Linguistics Research, https://www.eajournals.org/journals/inter national-journal-of-english-languageand-linguistics-research-ijellr/vol-8issue-3-may-2020/borrowing-techniqueas-reflected-in-the-rainbow-rowellsnovel-fangirl/. Accessed Wednesday December 2020.
[6] Syafrizal, Syafrizal. "The Correlation of Students' Learning Styles, Learning Motivation, and Speaking Ability." JELTS, vol. 3, no. 2, 2020, pp. 73-81. https://jurnal.untirta.ac.id/index.php/JEL TS/article/view/9543. Accessed Wednesday December 2020.

[7] J, Murphy. Turning around failing schools: Leadership lessons from the organizational sciences. Thousand Oaks, CA. Corwin Press, 2008.

[8] Juniardi, Yudi, and John Pahamzah. "Computer- vs. Mobile-Assisted Learning to Promote EFL Students' Speaking Skills: A Preliminary Classroom-Based Research." International Journal of Instruction, vol. 13, no. 3, 2020, pp. 417-432. http://eiji.net/volumes/362-july-2020,-volume13,-number-3. Accessed Monday December 2020.

[9] Sagala, S. (2009). Kemampuan Profesional Guru dan Tenaga Kependidikan. Bandung: Alfabeta.

[10] Mulyasa, A. (2003). Kurikulum Berbasis Kompetensi. Bandung: Remaja Rosda Karya.

[11] Donley, J. "Principals Competencies." Principals Competencies, Oakland, CA, $27 \quad 10 \quad 2020$, https://www.winginstitute.org/principalcompetencies-research. Accessed Monday December 2020.

[12] The Wing Institute. "Principal Competencies." Principal Competencies, The Winning Institute, 2710 2020, https://www.winginstitute.org/principalcompetencies-research. Accessed Monday December 2020.

[13] Mawadah, Ade Husnul, and John Pahamzah. "Early Grade Reading Assessment For Primary School Students In Serang Banten." Education, vol. 55, no. 4, 2020, pp. 696-702. http://jsju.org/index.php/journal/article/vi ew/702/696. Accessed Monday December 2020.

[14] Syafrizal Syafrizal, J. P. (2020). Language Assessment in English language teaching: A Washback of 
Indonesian Students' Test in COVID 19 Situation. Journal of Southwest Jiaotong University, 55(4).

[15] Kafle, Prisha. "The illusive alternative education in pandemic." Illusive alternative of education, Republica news, Wednesday December 2020, https://myrepublica.nagariknetwork.com/ news/the-illusive-alternative-educationin-pandemic/. Accessed Wednesday December 2020.

[16] Pahamzah, John. "Quizizz As A Students' Reading Comprehension Learning Media: A Case Study At The Eleventh Grade Of Dwi Putra Bangsa Vocational School In Cimanggu." International Journal of English Language and Linguistics Research, vol. 8, no. 5, 2020, pp. 27-33, https://www.eajournals.org/wpcontent/uploads/Quizizz-as-aStudents\%E2\%80\%99-ReadingComprehension-Learning-Media.pdf. Accessed Wednesday December 2020.
[17] Masrupi, and John Pahamzah. "Managing and Sustaining Human Competency in Pandemic Covid 19 through Sovereignty of Republic of Indonesia in the Era of 4.0." The International Journal of Business \& Management, vol. 8, no. 11, 2020, pp. 145-152.

IJBM, http://www.internationaljournalcorner.co m/index.php/theijbm/article/view/15670 0/108342. Accessed Wednesday December 2020

[18] Dirani, K. M., Abadi, M., Alizadeh, A., Barhate, B., Garza, R. C., Gunasekara, N., Majzun, Z. (2020). Leadership competencies and the essential role of human resource development in crisis times: a response to Covid-19 pandemic. Human Resource Development International, 23(4).

[19] Murfi, A., Fathurrochman, I., Atika, \& Jannana, N. S. (2020). Kepemimpinan Sekolah dalam Situasi Krisis Covid-19 di Indonesia. Manageria: Jurnal Manajemen Pendidikan Islam, 5(1), 119-136. 